\title{
Gamification and Scholarly Ethical Perspectives on Industries, A Bibliometric Analysis
}

\author{
Joseph W. Weiss \\ Bentley University \\ jweiss@bentley.edu
}

\begin{abstract}
Gamification applications are rapidly growing within industries, firms, and institutions as well as in consumer populations since the past decade. While this phenomenon is still in the early stages of development and diffusion, critics are voicing concerns over ethical and social responsibility issues underlying the intent and effects of questionable gamification uses with consumers, students, and employees. Results from this exploratory bibliometric analysis during this nascent period identifies occurrences of scholarly articles that used ethics perspectives related to gamification in particular industries. Our findings raise the following questions regarding ethics research and articles across industries, "Which industries have shown the most and least scholarly, academic publications using ethical perspectives? Is ethics research trending upward with the growth of gamification applications or not? Why, and should it?"
\end{abstract}

\section{Introduction}

The term "gamification" was first coined in 2003 by Nick Pelling, who described the process as striving to make products more fun and appealing to consumers by the use of games. Since then, this concept has evolved into a complex, and at times even controversial, topic. At opposite ends of the spectrum, gamification has been praised as an effective business strategy [1] Mollick and Werbach, (2014) and denounced as "exploitationware", created by marketers and corporations to manipulate consumers and reap profits [2] Due to the multidimensionality of its extensions, experts have yet to agree on a unifying definition of the concept. Two of the foremost experts on the subject, Sebastian Deterding and Juho Hamari, respectively define gamification as "the use of game elements in non- game contexts" and "the process of providing affordances for Gameful experiences. which support the customers' overall value creation," [3]. While these are the two most commonly accepted descriptions of gamification, within each field of study, classification varies slightly. For example, in the field of environmental sustainability, Froehlich (2014) [4] describes gamification as "the application of game design elements to help achieve a particular designed agenda or goal" within sustainability. Gamification within crowdsourcing and government is used to motivate individuals towards a vision [5]. Moreover, uses of gamification in other fields and industries such as education, healthcare, the military, marketing, and training and development is ongoing.

It is important to note that benefits from the use of gamification applications have been documented in healthcare, education, and industry-wide employee incentive and motivation training. Also, because of the entertainment attractiveness as well as scientific, developmental and educational uses of gamification, applications, economies internationally reflect the growth of this phenomenon. It is estimated that the global gamification market was valued at "USD 2.17 billion in 2017, and is expected to reach USD 19.39 billion by 2023."[6]

This estimated value includes not only gaming systems but supporting industries of gamification such as smartphones and mobile devices. Moreover, "gamification systems" are serving as a method to "architecture human behavior to induce innovation, productivity, or engagement. The use of gamification systems has also extended beyond their traditional scope of marketing, as now they are extensively used in advance applications like crowd sourcing," AI (artificial intelligence), and business process reengineering.[7]

While economic and business forecasts show a promising financial present and future for gamification applications in different industries, critics have and are voicing ethical warning signs 
regarding the intent and effects of such applications on students (since the education industry presently appears to be one of the most active users), employees, and consumers as we indicate next.

\section{Ethical Issues}

A relevant definition of ethics here is that it is a "set of concepts and principles that guide us in determining what behaviour helps or harms sentient creatures"[8] Andrzej Marczewski's use of ethics with regard to gamification designers and the systems which use such applications is also useful. [9] He states, "The emphasis here is on the intention of the gamification designer to create systems that help rather than bring harm to others, though defining harm is potentially subjective. When you build things, you can often become so attached to them that you become blind to potential criticism or dangers. This is why it is useful to have frameworks and ethical guidelines that prevent the potential dangers of personal morals, or lack thereof, overruling ethics."

Critics have identified salient ethical issues selected here that are associated with gamification applications, which can: (1) Exploit workers and take unfair advantage of employees; “...gamification proposes to replace real incentives with fictional ones ... Organizations ask for loyalty, but they reciprocate that loyalty with shames, counterfeit incentives that neither provide value nor require investment. When seen in this light, 'gamification' is a misnomer." [10] (2) Manipulate and infringe on workers' and customers' autonomy. For example, workers may not be informed about the practice and options of gamification: "One might say that in games, players sometimes endure seemingly unfair activities to achieve certain long-term objectives, even if they do not find an activity itself rewarding." [11] (3) Effect the moral character of involved parties. "An employer using leaderboards to shame poorperforming workers may be in a different ethical and social context than academic researchers using gamelike challenges to crowdsource scientific research, or a software provider making available a gameful tool to aid in weight loss." [12]. (4) Effects of games and gaming methods on participants may have a limiting effect on users achieving their full capability of either gamified solutions or in their work.[13].

While these ethical issues are not exhaustive, they are representative of harmful effects that designers and users of gamification applications can have on users. Another question this research can stimulate is, Do companies, organizations, employees and other stakeholders in specific industries have distinct issues that call for particular ethical and social responsibility attention? Or does 'One size fit all,' i.e. do specific industries require and benefit from general articles, codes, and ethical principles?

\section{Research Question and Methods}

Given the popularity of the uses of gamification in industries to motivate, engage, train, and educate employees, the main research question we posed was, To what extent are scholars investigating and addressing ethical implications of gamification applications and practices in different industries, as indicated by articles published in academic journals?

Bibliometric methods [14] [15] were used in this study to analyze citations from research published in reputable data bases identified below. Bibliometrics is an empirical method of using data and information to generate "citation frequencies and general overview of publications within a certain field." [16]. This type of research identifies and reveals what is happening now and trends from the past with regard to particular research questions.

Limitations of the bibliometric methodology as used here are also found in Bakker et al (2006) [17] and include the following: incomplete coverage of journals, issues, page numbers; unsystematic patterns and incorrect information. To correct for such commonplace errors, we used a team of graduate and undergraduate students along with a senior researcher and research librarian at the university to cross-check for errors and duplications of sources.

Our analysis in this inquiry covered five of the most common industries that implement gamification practices - professional, scientific, and technical services; educational services; health care and social assistance; management of companies and enterprises; and manufacturing, retail, and wholesale. Our research on gamification included eight NAICS industry categories (three industries were omitted due to lack of information).

This project also used the Web of knowledge database, along with others. This database was chosen because of its multidisciplinary nature and our need to cover all respective NAICS industries. The United States Census defines the North American Industry Classification System (NAICS) as the standard used by Federal statistical agencies in classifying business establishments.

The keyword "gamification" was paired, in turn, with ethic*, responsib*, justice, utilitarian, and moral.* Several readings of articles selected involved discarding trivial content as well any 
irrelevant articles such as book reviews and opinion, (op-ed) articles.

\section{Results}

Table 1 shows the total number of articles found in each database used between 2011 through March 23, 2016 that included both gamification and more specifically those articles that related ethics to gamification. A total of 987 articles were collected, 85 of which related ethics to gamification-8.6 percent of the total. Only academic journal articles were used and 10 articles were found to overlap within the ethical categories used in the search, explained earlier.

Figure 1 shows the percentage of ethics articles by industry. Table 2 presents a visual of the number of articles relating ethics to gamification by industry. As can be observed, the Educational Services

Table 1.

Databases

\begin{tabular}{lcl} 
Accessed* & & \\
\hline Database & $\begin{array}{l}\text { Number of } \\
\text { Gamification } \\
\text { Articles }\end{array}$ & $\begin{array}{l}\text { Number of } \\
\text { Ethical } \\
\text { Articles } \\
\text { Relating to } \\
\text { Gamification }\end{array}$ \\
\hline -Web of & 378 & 19 \\
$\begin{array}{l}\text { Knowledge } \\
\text {-EBSCO }\end{array}$ & 421 & 17 \\
-JSTOR & 6 & 3 \\
-ProQuest & 74 & 44 \\
-PubMed & 108 & 2 \\
\hline $\begin{array}{l}\text { All } \\
\text { databases }\end{array}$ & 987 & 85 \\
\hline *nly academic journals used; a 10 article \\
Qxerlap found within ethical categories
\end{tabular}

Industry had the largest percentage and number of academic ethical articles published as a field, followed by Information; then Health Care and Social Assistance; Arts, Entertainment \& Recreation; the other fields had relevant articles in single digits. Finance and Insurance and Retail Trade had the least articles dealing with ethics during this timeframe.

Figure 1 Percentage ethics articles by Industry 2011- through March, 232016

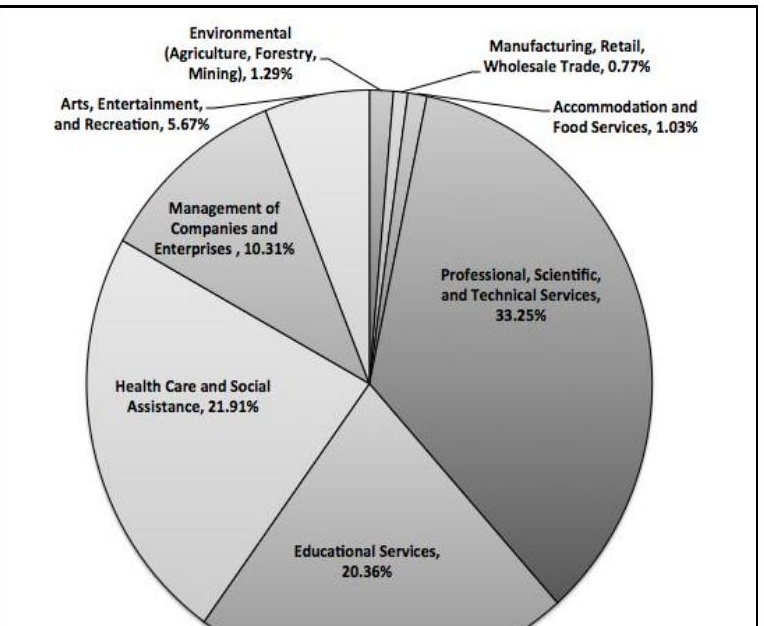

Table 2. Articles in All Databases: Ethical Components by NAICS Field.

\begin{tabular}{ll}
\hline NAICS Field & Number of Ethical Articles \\
\hline Construction (NAICS 23) & 2 \\
Manufacturing (NAICS 31-33) & 8 \\
Retail Trade (NAICS 44) & 1 \\
Information (NAICS 51) & 16 \\
$\begin{array}{l}\text { Finance and Insurance (NAICS 52) } \\
\text { Professional, Scientific, and Technical }\end{array}$ & 1 \\
$\quad$ Services (NAICS 54) & 6 \\
Management of Companies and Enterprises & 3 \\
$\quad$ NAICS 55) & 19 \\
Educational Services (NAICS 61) & 12 \\
Health Care and Social Assistance & \\
$\quad$ NAICS 62) & 10 \\
Arts, Entertainment, \& Recreation & \\
$\quad$ NAICS 71) & 3 \\
Accomodation and Food Services & 4 \\
$\quad$ Public Administratio (NAICS 72) & 85
\end{tabular}

Figure 2 shows the percentage of articles on gamification in general. There seems to be a correlation between those industries that show more academic articles on gamification in general and articles that deal with ethics in particular. This is an area of research that can be further analyzed. 
Figure 2. Gamification Articles from all databases by NAICS Field

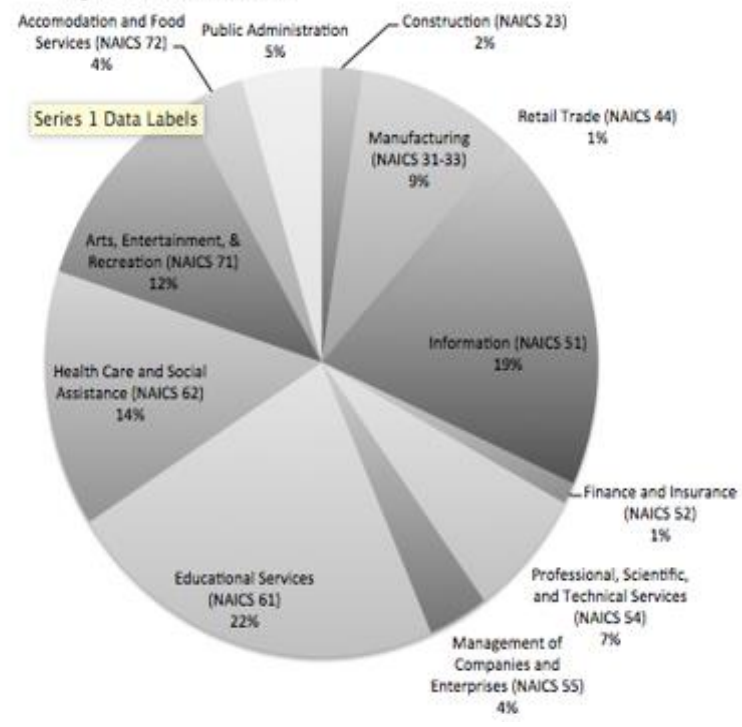

The results of our systematic review of collected data revealed that a majority of gamification research, over 90 percent, did not address ethical implications. Five articles referenced responsibility, two articles referenced morals, four articles referenced utilitarianism, and two articles referenced justice. Six of these articles demonstrated overlap in keywords, bringing the total count in "ethical" articles to nineteen. Of these articles, common ethical concerns regarding gamification included privacy, autonomy, manipulation, wellbeing, transparency, and exploitation. In addition, eleven of the "ethically" related articles were addressed in the industry of professional, scientific, and technical services; six articles dealt with the industry category of educational services, two pertained to accommodation and food services, one article could be categorized under the industry of management of companies and enterprises, and none of the ethical articles found related to environmental industries (agriculture, forestry, and mining), manufacturing, retail, and wholesale trade, health care and social assistance, and arts entertainment, and recreation. It is apparent from our data that the industries with the largest quantity of academic research also exhibited the most emphasis on ethics, excluding health care and social assistance. However, despite the presence of gamification ethics in industries, very little, if any, is said about corporate social responsibility.

\section{Conclusion and Discussion}

Our data shows that numbers of academic articles regarding gamification in general is dramatically increasing across several industries between 2011 and the first quarter of 2016. This, however, is not the case with articles dealing with ethics or social responsibility in most of these industries. Further research since 2016 may dispute this observation.. Secondly, the data also show that academic research is for the period covered in this study clearly skewed to four industries-professional, scientific, and technical services; health care and social assistance; educational services; and management of companies and enterprises. This is a curious finding, one that also can encourage further investigation.

Limitations of this study may help explain some of our questions and observations. First, academic articles may not be a major source of researching or dealing with ethical topics. Trade association publications, blogs, books, and other sources not covered in this study may be at play. This too is another topic for research and discussion. Secondly - and this is a question somewhat related to the above observation more than a limitation to this study-could it be that academic, formal research and articles are used less by industry leaders, HR and other specialists with regard to ethical issues, training, and communication? Also, do more general books, tapes, online courses, podcasts and consultants serve ethical and social responsibility needs of and organizations and industries?

Again, this study is aimed at stimulating further research, discussion, and debate among a wider audience of stakeholders (academics, industry and association leaders, consultants, universities, academic journal editors, employees, and students) into the nature of industries with regard to the prevalence or absence of academic research and publications on ethics, social responsibility, and gamification.

\section{References}

[1] E. Mollick and K. Werbach, "Gamification and the enterprise," in S. Walz \& S. Deterding (Eds.), The Gameful World: Approaches, Issues, Applications, 2014,

[2] F. Seaborn and D. Fels, "Gamification in theory and action: a survey." International Journal of Human-Computer Studies, 74, 2014, pp. 14-31.

[3] J. Hamari, "Transforming homo economicus into homo ludens: a field experiment on gamification in a utilitarian peer-to-peer trading 
service." Electronic Commerce Research and Applications, 12, 2013, pp. 236-245.

[4] J. Froehlich. "Gamifying green: gamification and environmental sustainability." In S. Walz \& S. Deterding (Eds.), The Gameful World: Approaches, Issues, Applications. Cambridge, MA: The MIT Press, 2014, pp.563-596.

[5] See [2]

[6] Global Gamification Market, Mordor Intelligence, Industry Reports, April, 2018, https://www.mordorintelligence.com/industryreports/gamification-market

[7] Ibid.

[8] B. R.Paul and L. Elder, L. "Miniature Guide to Ethical Reasoning. Foundation for Critical Thinking," 2003, https://www..critical thinking.org/files/Concepts \&Tools.pdf.

[9] A..Marczewski, "The Ethics of Gamification," , ACM Interactions IX, Fall, Vol. 24, No. 1, 2017, p. 56.

[10] I. Bogost, Persuasive games: Exploitationware. Gamasutra. May 3, ,2011,

http://www.gamasutra.com/view/feature/6366/persua sive games exploitationware.php; I. Bogost, "Why gamification is bullshit," in S. P. Walz and S. Deterding (Eds.), "The gameful world: Approaches, issues, applications," 2015, Cambridge: MIT Press; K. Werbach and Tae Wan Kim, "More than just a game: ethical issues in gamification." . Ethics and Information Technology 18 (2):, 2-16, pp.157-173

[11] Werbach; Werbach, K, \& Hunter, D. For the win: How game thinking can revolutionize your

business. Philadelphia: Wharton Digital Press., 2012.

[12] Ibid. p. 11

[13] Sami Hyrynsalmi and Jouni Smed, Kai K. Kimppa, "The Dark Side of Gamification: How We Should Stop Worrying and Study also the Negative Impacts of Bringing Game Design Elements to Everywhere," 2017, https://www.researchgate.net/publication/316755065_The Dark Side of Gamification How We Should Stop Worr ying_and_Study_also_the_Negative_Impacts_of_Bringing Game Design Elements to Everywhere

[14] E. Garfield,. "A bibliometric analysis of science journals in the ISI database." Science Citation Index. Journal Citation Reports, 1996.. Printed guide to the microfiche edition of the SCI JCR.
[15] W. Glänzel W. ,'A bibliometric approach to social sciences.' National research performance in 6 selected social science areas 1990-1992. Scientometrics. 35(3), 1996, pp. 291-307.

[16] H. Moed, H. 'The impact-factors debate: The ISI's uses and limits.' Nature , 415(6873), 2002, pp. 731-732.

[17] F. Bakker, P. Groenewegen, and F. Hond, F. , "A Research Note on the Use of Bibliometrics to Review the Corporate Social Responsibility and Corporate Social Performance Literature.” Business \& Society, 45(1), 2006. pp.7-19. 